\title{
The use of film coating on the performance of treated corn seed ${ }^{1}$
}

\author{
Suemar Alexandre Gonçalves Avelar²*, Fabianne Valéria de Sousa², Guilherme Fiss², \\ Leopoldo Baudet ${ }^{2}$, Silmar Teichert Peske ${ }^{2}$
}

\begin{abstract}
The main objective of seed coating technology using polymers is to improve the physical, physiological and sanitary characteristics of seed performance. The objectives of the present study were to determine: the plantability of corn seeds treated with insecticide, fungicide and graphite, covered with a film coating; the dust retention on treated corn seeds; and the leaching of applied products on corn seeds covered by a film coating. Seed plantability was determined by counting the skips and double seeds; dust was determined by using fiberglass paper in $\mathrm{mg} .100 \mathrm{~g}^{-1}$ of seeds; and the leaching was determined by collecting the material leached in a $10 \mathrm{~cm}$ layer of sand after irrigation. The following conclusions were made: seeds covered with film coating effectively reduce skips and double seeds; film coating effectively reduces the formation of dust from the seeds; film coated seeds minimize the leaching of the insecticide applied in seed treatment; and there are differences in effectiveness related to film coating type and dosage.
\end{abstract}

Index terms: polymer, plantability, dust, leaching.

\section{Uso de film coating e desempenho de sementes de milho tratadas}

\begin{abstract}
RESUMO - A tecnologia do recobrimento de sementes com uso de polímeros tem como principal objetivo melhorar o desempenho de sementes em relação aos atributos físicos, fisiológicos e sanitários. Nesse contexto, os objetivos desse estudo foram determinar: a plantabilidade de sementes de milho tratadas com inseticida, fungicida e grafite, cobertas com film coating; a retenção de poeira em sementes de milho tratadas; e a lixiviação de produtos aplicados em sementes de milho recobertas por film coating. A plantabilidade das sementes foi determinada pela contagem de falhas e duplas. A poeira foi determinada usando papéis de fibra de vidro em mg. $100 \mathrm{~g} \mathrm{~g}^{-1}$ de sementes. A lixiviação foi determinada pela coleta de material lixiviado em uma camada de $10 \mathrm{~cm}$ de areia após irrigação. As seguintes conclusões foram obtidas: sementes recobertas com film coating reduzem falhas e duplas na semeadura; film coating reduz formação de poeira nas sementes; sementes recobertas por film coating apresentam menores índices de lixiviação de inseticida aplicado no tratamento de sementes; e há diferença em eficiência em relação ao tipo de film coating e na dosagem utilizada.
\end{abstract}

Termos para indexação: polímero, plantabilidade, poeira, lixiviação.

\section{Introduction}

The use of high physiological quality seeds is among the best practices for obtaining maximum crop yields. These seeds are more likely to achieve a high performance when exposed to different environmental conditions, expressed in a high percentage and speed of emergence, good stand establishment, good initial seedling development (Tillmann and Miranda, 2006) and increased final production. During seed production several strategies are adopted to ensure a high seed quality.

After sowing, seeds are still exposed to biotic and abiotic environmental factors (Delouche, 2005) and agricultural soils have many pathogenic microorganisms that may interact with seeds and seedlings (Munkvold and O'Mara, 2002),

\footnotetext{
${ }^{1}$ Submitted on 11/11/2010. Accepted for publication on $02 / 04 / 2012$.

${ }^{2}$ Departamento de Fitotecnia, Universidade Federal de Pelotas (UFPEL), Caixa Postal 354, 96001-970 - Capão do Leão, RS, Brasil.

*Corresponding author <suemaralexandre@yahoo.com.br>
} 
and can reduce their performance causing seed rot, seedling death or root rot (Pinto, 2000). Phytophagous insects in the soil can also damage seedlings (Girolami et al., 2009), and significantly reduce the plant population.

In this context, seed treatment is an alternative for improving seed and seedling performance. Treatment of corn seeds with the fungicides difeconazole, fludioxinol and Captan has proved to be efficient in controlling Fusarium, although there are differences in efficacy for the different pathogen species, with the former two being generally more effective than Captan (Munkvold and O'Mara, 2002). Seed treatment with insecticides of the neonicotinoid group (systemic action), for example, protect seedlings from the attack of several phytophagous insects (Elbert et al., 2008).

To improve the efficiency of seed treatment, the use an adhesive polymer is recommended, creating a "film coating" on the seed surface; this technology allows the application of several products and multiple coatings (Taylor and Harman, 1990). This sophisticated application process, besides allowing a precise distribution of active ingredients on the seed surface without changing its shape and causing a weight gain of at most $2 \%$, may also allow a better adhesion and protection for fungicides and insecticides (Kunkur et al., 2007). Rivas et al. (1998) and Pereira et al. (2005) verified that the use of polymers does not affect the physiological quality of corn seeds or interfere in the chemical treatment effect of high quality seeds. Karam et al. (2007) found that polymers did not affect viability, vigor or the longevity of corn seeds.

There are several studies that discuss the influence of polymer use in seed treatment related to seed physiological quality and performance of many species, both for crop establishment in the field and during storage. However, there is a lack of information on how the different polymers interact with the seed physical properties of different species and with the different products used for seed treatment.

Therefore, the objectives of the present study were to determine: the plantability of corn seeds treated with insecticide, fungicide and graphite, covered with film coating; the dust retention on treated corn seeds; and the leaching of applied products on corn seeds covered by film coating.

\section{Materials and Methods}

\section{Experiment 1 - Plantability}

Manually graded corn seeds (using screens with oblongperforations of $6 \times 19 \mathrm{~mm}$ and with round perforations of $7.75 \mathrm{~mm}$ ) were treated as described in Table 1.
Coating and seed treatment were manually done using $700 \mathrm{~g}$ of seeds per experimental unit with application of the product mix and water, so that the total volume (product + water) reached $1500 \mathrm{~mL} .100 \mathrm{~kg}^{-1}$. The seeds were treated in plastic bags, adding the products to the seeds and then shaking them for a minute until the complete distribution of the products on the seed surface was achieved.

The seed plantability test was done using a seed dispenser mechanism on a bench, composed of an electric motor with a speed regulator, a system of seed distribution with a perforated disc, and a conveyor belt in $\mathrm{V}$-shape, connected to an electric motor set to run at $3.0 \mathrm{~km} . \mathrm{h}^{-1}$ with a seeding rate of 5 seeds. $\mathrm{m}^{-1}$ (nominal spacing $=$ distance between seeds of $0.2 \mathrm{~m}$ ). The assessment of skip percentage was performed with the treadmill in motion, running a distance of 137 linear meters, considering the distance between seeds greater than 1.5 times the nominal spacing and concomitantly the percentage of doubles was evaluated, with a distance smaller than 0.5 times the nominal spacing being considered as double.

The angle of repose using a sample of $700 \mathrm{~g}$, set in a box with dimensions of $0.15 \times 0.30 \times 0.30 \mathrm{~m}$ was also determined. The box had a division in the middle, where one side was filled with seeds. After the division was removed allowing the seeds to flow, the angle of repose was calculated by the arc tan $a \cdot b^{-1}$, being "a" equal to the seed weight height in the corner of the box and " $b$ " the distance where the seed flows horizontally, according to the methodology described by (Mantovani et al.,1999).

\section{Experiment 2 - Dust retention}

The dust retention test was performed in specific equipment, known as the HEUBACH dustmeter, to observe the dust loss in seeds. Previously weighed fiber glass papers were used and taken from the machine where the dust was impregnated in the paper and weighed again to determine dust loss. Two replications for each experimental unit were used with $100 \mathrm{~g}$ of seeds.

A completely randomized design was used, with a total of 18 treatments and three replications. Mean values were submitted to variance analysis and the Scott-Knott test at a $5 \%$ probability level.

\section{Experiment 3 - Leaching}

A quantity of $100 \mathrm{~g}$ of corn seeds received the treatments as described in Table 2. The coating and seed treatments were made in plastic bags, according to the methodology described in Experiment 1, except for the total volume (product plus water), which was $2400 \mathrm{~mL}$. 
Table 1. Treatment identification and dosages of the products used for corn seed treatment. Experiments 1 and 2.

\begin{tabular}{|c|c|}
\hline Treatments & $\begin{array}{c}\text { Dosage } \\
\left(\mathrm{mL} \text { of water. } 100 \mathrm{~kg}^{-1}\right)\end{array}$ \\
\hline ColorSeed C3 $^{1}+$ Imidacloprid $^{7}+$ Fungicide $^{8}$ & 700 \\
\hline ColorSeed $\mathrm{HE}^{2}+$ Imidacloprid $^{7}+$ Fungicide $^{8}$ & 670 \\
\hline PolySeed $\mathrm{CF}^{3}+$ Imidacloprid $^{7}+$ Fungicide $^{8}$ & 720 \\
\hline ColorSeed C $^{4}+$ Imidacloprid $^{7}+$ Fungicide $^{8}$ & 650 \\
\hline ColorSeed HE $^{5}+$ Imidacloprid $^{7}+$ Fungicide $^{8}$ & 630 \\
\hline PolySeed $\mathrm{CF}^{6}+$ Imidacloprid $^{7}+$ Fungicide $^{8}$ & 690 \\
\hline ColorSeed C $^{1}+$ Thiametoxan $^{7}+$ Fungicide $^{8}$ & 700 \\
\hline 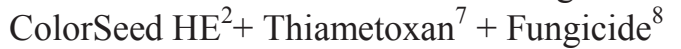 & 670 \\
\hline PolySeed $\mathrm{CF}^{3}+$ Thiametoxan $^{7}+$ Fungicide $^{8}$ & 720 \\
\hline 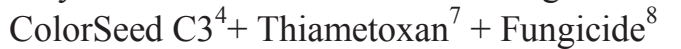 & 650 \\
\hline ColorSeed HE $^{5}+$ Thiametoxan $^{7}+$ Fungicide $^{8}$ & 630 \\
\hline PolySeed $\mathrm{CF}^{6}+$ Thiametoxan $^{7}+$ Fungicide $^{8}$ & 690 \\
\hline No polymer + Imidacloprid ${ }^{7}+$ Fungicide $^{8}$ & 750 \\
\hline No polymer Thiametoxan ${ }^{7}+$ Fungicide $^{8}$ & 750 \\
\hline Graphite $^{9}+$ Imidacloprid $^{7}+$ Fungicide $^{8}$ & 750 \\
\hline Graphite $^{9}+$ Thiametoxan $^{7}+$ Fungicide $^{8}$ & 750 \\
\hline Graphite & 1500 \\
\hline
\end{tabular}

${ }^{1} 50 \mathrm{~mL} .100 \mathrm{~kg}^{-1} ;{ }^{2} 80 \mathrm{~mL} .100 \mathrm{~kg}^{-1} ;{ }^{3} 30 \mathrm{~mL} .100 \mathrm{~kg}^{-1} ;{ }^{4} 100 \mathrm{~mL} .100 \mathrm{~kg}^{-1} ;{ }^{5} 120 \mathrm{~mL} .100 \mathrm{~kg}^{-1} ;{ }^{6} 60 \mathrm{~mL} .100 \mathrm{~kg}^{-1} ;{ }^{7} 600 \mathrm{~mL} .100 \mathrm{~kg}^{-1} ;{ }^{8}$ Fludioxinil + Metalaxyl M $\left(150 \mathrm{~mL} .100 \mathrm{~kg}^{-1}\right) ;{ }^{9} 400 \mathrm{~g} .100 \mathrm{~kg}^{-1}$.

Table 2. Treatment identification and dosages of the products used for corn seed treatment. Experiment 3.

\begin{tabular}{|c|c|}
\hline Treatments & $\begin{array}{c}\text { Dosage } \\
\left(\mathrm{mL} \text { of water. } 100 \mathrm{~kg}^{-1}\right)\end{array}$ \\
\hline ColorSeed C3 ${ }^{1}+$ Leach $^{7}$ & 50 \\
\hline ColorSeed $\mathrm{HE}^{2}+$ Leach & 70 \\
\hline PolySeed $70^{3}+$ Leach & 110 \\
\hline ColorSeed $\mathrm{C} 3^{4}+$ Leach & 0 \\
\hline ColorSeed $\mathrm{HE}^{5}+$ Leach & 30 \\
\hline PolySeed $70^{6}+$ Leach & 70 \\
\hline Leach & 150 \\
\hline Untreated & - \\
\hline
\end{tabular}

${ }^{1} 100 \mathrm{~mL} .100 \mathrm{~kg}^{-1} ;{ }^{2} 80 \mathrm{~mL} .100 \mathrm{~kg}^{-1} ;{ }^{3} 40 \mathrm{~mL} .100 \mathrm{~kg}^{-1} ;{ }^{4} 150 \mathrm{~mL} .100 \mathrm{~kg}^{-1}$; ${ }^{5} 120 \mathrm{~mL} .100 \mathrm{~kg}^{-1} ;{ }^{6} 80 \mathrm{~mL} .100 \mathrm{~kg}^{-1}$; ${ }^{7}$ Insecticide Furazin $310 \mathrm{TS} / 210 \mathrm{~g}$ of $\mathrm{Zn}$ per liter $\left(2250 \mathrm{~mL} .100 \mathrm{~kg}^{-1}\right)$.

After treatment, 50 seeds per experimental unit were sown on the surface of polypropylene cups with a perforated bottom and capacity of $500 \mathrm{~cm}^{3}$, and containing a layer of $7 \mathrm{~cm}$ of sterilized sand. After sowing, seeds were covered with a layer of $3 \mathrm{~cm}$ of sand, simulating a $10 \mathrm{~cm}$ layer of soil with seeds sowed at $3 \mathrm{~cm}$ depth.

Then, the seeds were subjected to rainfall of $50 \mathrm{~mm}$, with the water added to the cups using a $1000 \mathrm{~mL}$ graduated beaker. The leachate was collected in $100 \mathrm{~cm}^{3}$ polypropylene cups and sent to a soil analysis laboratory for chemical analysis of zinc in the solution. The zinc was measured by atomic absorption spectrophotometry, and was the element chosen since Furazin 310 TS used for seed treatment contains $210 \mathrm{~g}$ of zinc per liter.

A completely randomized design with eight treatments and four replications was used, with a total of 32 experimental units. The data were subjected to a variance analysis and when the mean values presented significant differences, data were submitted to the Scott-Knott test for mean separation at the $5 \%$ probability level.

\section{Experiment 1 - Plantability}

The seed treatments showed statistical differences as evaluated from the number of seeds. $\mathrm{m}^{-1}$, skips, doubles and angle of repose (Table 3 ).

All treatments showed a distribution of seeds per meter equal or higher than 5 seeds. $\mathrm{m}^{-1}$ as planned (Table 3). However, treatments containing graphite had significantly more seeds per meter than the others, showing the difficulty in achieving the proper seeding rate due to seed flowability. 
Table 3. Number of seeds per meter * (NSM), skips ( $\%)$, doubles ( $\%)$ and angle of repose (AR) in sowing evaluation using treated corn seeds.

\begin{tabular}{|c|c|c|c|c|}
\hline Treatments & NSM & Skips (\%) & Double (\%) & AR \\
\hline 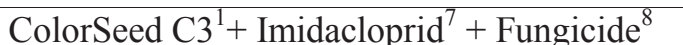 & $5.3 \mathrm{a}$ & $2.2 \mathrm{a}$ & $8.9 \mathrm{a}$ & $30.5 \mathrm{a}$ \\
\hline 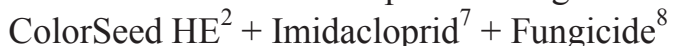 & $5.3 \mathrm{a}$ & $2.2 \mathrm{a}$ & $8.4 \mathrm{a}$ & $28.7 \mathrm{a}$ \\
\hline PolySeed $\mathrm{CF}^{3}+$ Imidacloprid $^{7}+$ Fungicide $^{8}$ & $5.1 \mathrm{a}$ & $2.7 \mathrm{a}$ & $7.2 \mathrm{a}$ & $32.6 \mathrm{a}$ \\
\hline ColorSeed $\mathrm{C}^{4}+$ Imidacloprid $^{7}+$ Fungicide $^{8}$ & $5.0 \mathrm{a}$ & $3.9 \mathrm{~b}$ & $7.3 \mathrm{a}$ & $30.0 \mathrm{a}$ \\
\hline 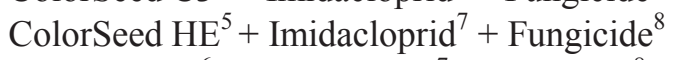 & $5.2 \mathrm{a}$ & $4.3 \mathrm{~b}$ & $9.3 \mathrm{a}$ & $31.4 \mathrm{a}$ \\
\hline PolySeed $\mathrm{CF}^{6}+$ Imidacloprid $^{7}+$ Fungicide $^{8}$ & $5.3 \mathrm{a}$ & $2.2 \mathrm{a}$ & $8.7 \mathrm{a}$ & $31.1 \mathrm{a}$ \\
\hline ColorSeed $3^{1}+$ Thiametoxan $^{7}+$ Fungicide $^{8}$ & $5.4 \mathrm{a}$ & $1.8 \mathrm{a}$ & $8.6 \mathrm{a}$ & $29.7 \mathrm{a}$ \\
\hline ColorSeed $\mathrm{HE}^{2}+$ Thiametoxan $^{7}+$ Fungicide $^{8}$ & $5.4 \mathrm{a}$ & $1.5 \mathrm{a}$ & $7.4 \mathrm{a}$ & $32.1 \mathrm{a}$ \\
\hline PolySeed $\mathrm{CF}^{3}+$ Thiametoxan $^{7}+$ Fungicide $^{8}$ & $5.3 \mathrm{a}$ & $2.2 \mathrm{a}$ & $8.3 \mathrm{a}$ & $30.0 \mathrm{a}$ \\
\hline ColorSeed $3^{4}+$ Thiametoxan $^{7}+$ Fungicide $^{8}$ & $5.3 \mathrm{a}$ & $2.0 \mathrm{a}$ & $9.6 \mathrm{a}$ & $31.2 \mathrm{a}$ \\
\hline ColorSeed $\mathrm{HE}^{5}+$ Thiametoxan $^{7}+$ Fungicide $^{8}$ & $5.4 \mathrm{a}$ & $1.7 \mathrm{a}$ & $8.3 \mathrm{a}$ & $31.3 \mathrm{a}$ \\
\hline PolySeed $\mathrm{CF}^{6}+$ Thiametoxan $^{7}+$ Fungicide $^{8}$ & $5.3 \mathrm{a}$ & $2.0 \mathrm{a}$ & $9.1 \mathrm{a}$ & $33.7 \mathrm{a}$ \\
\hline No polymer + Imidacloprid $^{7}+$ Fungicide $^{8}$ & $5.2 \mathrm{a}$ & $3.0 \mathrm{~b}$ & $7.2 \mathrm{a}$ & $31.0 \mathrm{a}$ \\
\hline No polymer Thiametoxan $^{7}+$ Fungicide $^{8}$ & $5.2 \mathrm{a}$ & $3.2 \mathrm{~b}$ & $9.7 \mathrm{a}$ & $29.6 \mathrm{a}$ \\
\hline Graphite $^{9}+$ Imidacloprid $^{7}+$ Fungicide $^{8}$ & $5.8 \mathrm{~b}$ & $3.2 \mathrm{~b}$ & $13.4 \mathrm{~b}$ & $20.9 \mathrm{~b}$ \\
\hline Graphite $^{9}+$ Thiametoxan $^{7}+$ Fungicide $^{8}$ & $6.0 \mathrm{~b}$ & $4.0 \mathrm{~b}$ & $14.6 \mathrm{~b}$ & $21.6 \mathrm{~b}$ \\
\hline Graphite & $5.8 \mathrm{~b}$ & $3.0 \mathrm{~b}$ & $15.5 \mathrm{~b}$ & $21.4 \mathrm{~b}$ \\
\hline Untreated & $5.3 \mathrm{a}$ & $2.2 \mathrm{a}$ & $8.9 \mathrm{a}$ & $22.5 \mathrm{~b}$ \\
\hline CV $(\%)$ & 5.5 & 27.3 & 13.4 & 15.8 \\
\hline
\end{tabular}

*Mean values followed by same letter in the column do not differ statistically from each other (Scott-Knott, $5 \%$ ).

${ }^{1} 50 \mathrm{~mL} .100 \mathrm{~kg}^{-1} ;{ }^{2} 80 \mathrm{~mL} .100 \mathrm{~kg}^{-1} ;{ }^{3} 30 \mathrm{~mL} .100 \mathrm{~kg}^{-1} ;{ }^{4} 100 \mathrm{~mL} .100 \mathrm{~kg}^{-1} ;{ }^{5} 120 \mathrm{~mL} .100 \mathrm{~kg}^{-1} ;{ }^{6} 60 \mathrm{~mL} .100 \mathrm{~kg}^{-1} ;{ }^{7} 600 \mathrm{~mL}^{2} 100 \mathrm{~kg}^{-1} ; \quad{ }^{8}$ Fludioxinil + Metalaxyl $\mathrm{M}\left(150 \mathrm{~mL} .100 \mathrm{Kg}^{-1}\right) ;{ }^{9} 400 \mathrm{~g} .100 \mathrm{~kg}^{-1}$

Seeds coated with the polymer PolySeed CF showed a statistically lower percentage of skips compared to seeds treated with graphite, those with no polymer or treated with other polymers at a higher dosage (Table 3), with differences being almost twice as large in some cases.

Regardless of the treatment, seeds coated with polymers showed a lower percentage of doubles than those treated with graphite, with or without insecticide and fungicide (Table 3). In this case, some treatments with polymers also showed a difference $50 \%$ lower than for seeds coated with graphite.

Seed treatment with or without polymers increased the angle of repose when compared to the control and to seeds coated with graphite associated with an insecticide and fungicide. The lower angle of repose of the seeds treated with graphite means that seeds stick less to each other and will flow faster during the sowing procedure.

According to the adjustment of the machine distribution system for sowing five seeds per meter in an area of $100 \mathrm{~m} \times 100 \mathrm{~m}$ (1 hectare), using a row spacing of $0.8 \mathrm{~m}$, the population density is 62,500 plants.ha $^{-1}$. In the Graphite + Thiametoxan + Fungicide treatment, on average, six seeds per meter with a density of 75,000 plants.ha ${ }^{-1}$, were obtained, totalizing an increase of 12,500 plants.ha ${ }^{-1}$. Considering the seed cost at around US $\$ 0.01$, there would be an increase of US\$125.00.ha ${ }^{-1}$ over the total cost of crop establishment.

On the other hand, the percentage of skips and doubles pointed to a more uniform distribution using the film coating and a non-uniform distribution with graphite, which can result in a suitable plant population and a higher yield, as pointed out by (Schuch et al., 2000). The treatment Graphite + Thiametoxan + Fungicide can show a reduction of 4\% in plant density in some areas while in others, the same treatment can increase the plant population by $14.6 \%$. The grain yield potential of corn has been found to be dependent on plant density. Doubles and skips are two attributes that affect plant distribution in the field causing an uneven spacing between the plants, which reduces the yield potential of a given crop. Plants do compensate for skips producing more canopy, which is not sufficient if a normal plant is present. On the other hand, with double plants, the competition between them also reduces the yield of the population. Therefore 
both lower or higher densities result in a yield reduction (Ipsilandis and Vafias, 2005). This fact emphasizes the importance of seeding precision to achieve the best performance and assure high economic returns.

The results for graphite agree with Mantovani et al. (1999), who verified that the graphite use in treated corn seeds plays an important role in improving flowability, but do disagree in relation to the higher efficiency obtained by the authors with graphite.

The ease of flow in the seed reservoir depends, among other factors, on the coefficient of internal friction of the seeds and between them and the seed reservoir walls. The coefficient of friction and the angle of repose can be assumed to be of the same magnitude (Mantovani et al., 1999). Graphite use caused an increase in double percentages, in some treatments close to $75 \%$, compared to the control, which probably led to the highest number of skips, increasing the lack of uniformity in the distribution. The number of seeds and the doubles seem to be related to the angle of repose.

\section{Experiment 2 - Dust retention}

The polymer treatments showed reduced dust formation from the seeds to a higher or lower extent, depending on dosage and the combination of treatments, when compared with seeds treated with no polymers and those treated with graphite. However, seeds with graphite, when treated with Thiametoxan showed a similar behavior, with some combinations of polymers and products (Table 4).

Table 4. Amount of dust from corn seeds submitted to different treatments.

\begin{tabular}{|c|c|}
\hline Treatments & Dust mg.100 $\mathrm{g}^{-1}$ \\
\hline ColorSeed C $^{1}+$ Imidacloprid $^{7}+$ Fungicide $^{8}$ & $2.5 \mathrm{~b}$ \\
\hline 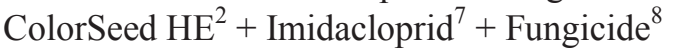 & $0.1 \mathrm{a}$ \\
\hline PolySeed $\mathrm{CF}^{3}+$ Imidacloprid $^{7}+$ Fungicide $^{8}$ & $0.1 \mathrm{a}$ \\
\hline ColorSeed $3^{4}+$ Imidacloprid $^{7}+$ Fungicide $^{8}$ & $0.1 \mathrm{a}$ \\
\hline ColorSeed HE + Imidacloprid $^{7}+$ Fungicide $^{8}$ & $0.1 \mathrm{a}$ \\
\hline PolySeed $\mathrm{CF}^{6}+$ Imidacloprid $^{7}+$ Fungicide $^{8}$ & $0.1 \mathrm{a}$ \\
\hline ColorSeed C $^{1}+$ Thiametoxan $^{7}+$ Fungicide $^{8}$ & $0.1 \mathrm{a}$ \\
\hline 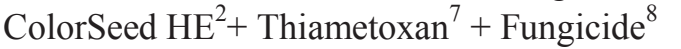 & $0.1 \mathrm{a}$ \\
\hline PolySeed $\mathrm{CF}^{3}+$ Thiametoxan $^{7}+$ Fungicide $^{8}$ & $2.8 \mathrm{~b}$ \\
\hline 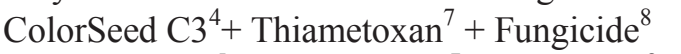 & $2.8 \mathrm{~b}$ \\
\hline 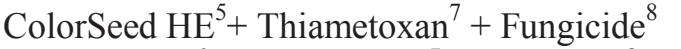 & $2.5 \mathrm{~b}$ \\
\hline PolySeed $\mathrm{CF}^{6}+$ Thiametoxan $^{7}+$ Fungicide $^{8}$ & $0.1 \mathrm{a}$ \\
\hline No polymer + Imidacloprid $^{7}+$ Fungicide $^{8}$ & $4.0 \mathrm{c}$ \\
\hline No polymer Thiametoxan ${ }^{7}+$ Fungicide $^{8}$ & $3.5 \mathrm{c}$ \\
\hline Graphite $^{9}+$ Imidacloprid $^{7}+$ Fungicide $^{8}$ & $4.5 \mathrm{c}$ \\
\hline Graphite $^{9}+$ Thiametoxan $^{7}+$ Fungicide $^{8}$ & $3.2 \mathrm{~b}$ \\
\hline Graphite & $8.5 \mathrm{~d}$ \\
\hline Untreated & $0.1 \mathrm{a}$ \\
\hline CV $(\%)$ & 42.4 \\
\hline
\end{tabular}

* Mean values followed by same letter in the column do not differ statistically from each other (Scott-Knott, 5\%).

${ }^{1} 50 \mathrm{~mL} .100 \mathrm{~kg}^{-1} ;{ }^{2} 80 \mathrm{~mL} .100 \mathrm{~kg}{ }^{-1} ;{ }^{3} 30 \mathrm{~mL} .100 \mathrm{~kg}^{-1} ;{ }^{4} 100 \mathrm{~mL} .100 \mathrm{~kg}{ }^{-1} ;{ }^{5} 120 \mathrm{~mL} .100 \mathrm{~kg}^{-1} ;{ }^{6} 60 \mathrm{~mL} .100 \mathrm{~kg}{ }^{-1} ;{ }^{7} 600 \mathrm{~mL} .100 \mathrm{~kg}{ }^{-1} ;{ }^{8}$ Fludioxinil + Metalaxyl $\mathrm{M}\left(150 \mathrm{~mL} .100 \mathrm{Kg}^{-1}\right) ;{ }^{9} 400 \mathrm{~g} .100 \mathrm{~kg}^{-1}$

Some seed treatment combinations with film coating showed a very low dust level ( $0.1 \mathrm{mg} .100$ seeds $\left.\mathrm{g}^{-1}\right)$, when compared with seeds treated without polymer or with graphite, while others showed a reduction from $20 \%$ to $35 \%$ in dust, and almost $70 \%$ if compared with seed treated only with graphite.

The dust formation in treated seeds is related to the adherence of products to the seeds, indicating compatibility between the formulations and product loss after treatment and, consequently, inefficiency because seeds will not have the expected protection (Avelar et al., 2009). The use of a film coating improves seed treatment standards, stability and adhesion, causes a reduction in environmental 
impact by toxic dust and assures seed protection, besides minimizing the exposure of natural enemies to active ingredients during seeding.

\section{Experiment 3 - Leaching}

In the leaching test, the polymer PolySeed CF was the most effective treatment for fungicide retention on a zinc basis in coated corn seeds, independent of the dosage (Table 5).

Table 5. Leaching of zinc from corn seeds treated with Furazin and coated with polymers after an irrigation depth of $50 \mathrm{~mm}$.

\begin{tabular}{lc}
\hline \multicolumn{1}{c}{ Treatment } & $\begin{array}{c}\text { Zn } \\
\left(\mathrm{Mg} . \mathrm{L}^{-1}\right)\end{array}$ \\
\hline Colorseed C3 $\left(100 \mathrm{~mL} .100 \mathrm{~kg}^{-1}\right)+$ Leach** & $1.33 \mathrm{c}^{*}$ \\
Colorseed HE $\left(80 \mathrm{~mL} .100 \mathrm{~kg}^{-1}\right)+$ Leach & $0.96 \mathrm{~b}$ \\
Polyseed $70\left(40 \mathrm{~mL} .100 \mathrm{~kg}^{-1}\right)+$ Leach & $0.17 \mathrm{a}$ \\
Colorseed C3 $\left(150 \mathrm{~mL} .100 \mathrm{~kg}^{-1}\right)+$ Leach & $1.83 \mathrm{~d}$ \\
Colorseed HE $\left(120 \mathrm{~mL} .100 \mathrm{~kg}^{-1}\right)+$ Leach & $1.27 \mathrm{c}$ \\
Polyseed $70\left(80 \mathrm{~mL} .100 \mathrm{~kg}^{-1}\right)+$ Leach & $0.13 \mathrm{a}$ \\
Leach & $0.79 \mathrm{~b}$ \\
Untreated & $0.05 \mathrm{a}$ \\
\hline CV $(\%)$ & 21.5 \\
\hline
\end{tabular}

* Mean values followed by same letter in the column do not differ statistically from each other (Scott-Knott, $5 \%$ ).

** Insecticide Furazin 310 TS / 210 g of Zn per liter (2250 mL.100 kg-1).

The retention of product with seed treatment also depends on the adherence of the applied products, compatibility between the different formulations used and the characteristics of the seed coat. The polymer PolySeed CF showed a high efficiency in processing, with a leaching effect similar to untreated seeds, while seeds treated only with the leachate showed a leaching higher than 15 times that of untreated seeds and five times that of treated seeds and PolySeed CF.

This result confirmed the compatibility of the product used, reflected in a high adherence of products on the seeds, even after the simulated rainfall. This will assure an adequate protection of the seeds, besides reducing environmental impacts, such as soil contamination and leaching of pesticides into the ground-water.

Some polymers did not have the same efficiency, showing, in some cases, a leaching higher than for seeds treated without polymers, like the polymer ColorSeed C3, for example, that presented a leaching twice as high as the control. This may be attributed to an incompatibility between these polymers and the product used, resulting in a reduction in the adherence. When the water washes the soil in which the seeds are sown with these products, the small adherence of these products allows solubilization, causing higher losses.

\section{Conclusions}

Seed coating with polymers improves plantability, reducing the percentage of skips and doubles; polymers reduce the formation of dust from seeds; polymers minimize insecticide leaching from treated corn seed; and there is a difference for treatment efficiency, associated with the polymer and the dosage used.

\section{References}

AVELAR, S.A.G.; BAUDET, L.; VILLELA, F.A. The improvement of the seed treatment process, Seed News, v.XIII, n.5, p.8-11, 2009.

DELOUCHE, J.C. Seed quality and performance. Seed News, v.9, n.5, p.34-35, 2005.

ELBERT, A.; HAAS, M.; SPRINGER, B.; THIELERT, W.; NAUEN, R. Applied aspects of neonicotinoid uses in crop protection. Pest Management Science, v.64, n.11, p.1099-1105, 2008. http://onlinelibrary. wiley.com/doi/10.1002/ps.1616/abstract

GIROLAMI, V.; MAZZON, L.; SQUARTINI, A.; MORI, N.; MARZARO, M.; DI BERNARDO, A.; GREATTI, M.; GIORIO, C.; TAPPARO, A. Translocation of neonicotinoid insecticides from coated seeds to seedling guttation drops: a novel way of intoxication for bees. Journal of Economic Entomology, v.102, n.5, p.1808-1815, 2009. http:// docserver.ingentaconnect.com/deliver/connect/esa/00220493/v102n5/ s11.pdf?expires $=1289435766 \&$ id $=0000 \&$ titleid $=10264 \&$ checksum $=9 \mathrm{~B}$ 9AEEFF22E42F69B71153E65B80732D

IPSILANDIS, C.G.; VAFIAS, B.N. Plant density effects on grain yield per plant in maize: Breeding implications. Asian Journal of Plant Science, v.4, n.1, p.31-39, 2005. http://scialert.net/qredirect.php?doi=aj ps.2005.31.39\&linkid=pdf

KARAM, D.; MAGALHÃES, P.C.; PADILHA L. Efeito da adição de polimeros na viabilidade, no vigor e na longevidade de sementes de milho. Sete Lagoas: Embrapa Milho e Sorgo. 2007. 6p. (Embrapa Milho e Sorgo, Circular Técnica 94). http://www.cnpms.embrapa.br/publicacoes/ publica/2007/circular/Circ_94.pdf

KUNKUR, V.; HUNJE, R.; PATIL, N.K.B.; VYAKARNHAL, B.S. Effect of seed coating with polymer, fungicide and insecticide on seed quality in cotton during storage. Karnataka Journal of Agricultural Sciences, v.20, n.1, p.137-139, 2007. http://203.129.218.157/ojs/index. php/kjas/article/viewFile/42/42

MANTOVANI, E.C.; MANTOVANI, B.H.M.; CRUZ, I.; MEWES, W.L.C.; 
OLIVEIRA, A.C. Desempenho de dois sistemas distribuidores de sementes utilizados em semeadoras de milho. Pesquisa Agropecuária Brasileira, v.34, n.1, p.93-98, 1999. http://www.scielo.br/pdf/pab/v34n1/8714.pdf

MUNKVOLD, G.P.; O'MARA, J.K. Laboratory and growth chamber evaluation of fungicidal seed treatments for maize seedling blight caused by Fusarium species. Plant Disease, v.86, n.2, p.143-150, 2002. http:// apsjournals.apsnet.org/doi/pdf/10.1094/PDIS.2002.86.2.143

PEREIRA, C.E.; OLIVEIRA, J.A.; EVANGELISTA, J.R.E. Qualidade fisiológica de sementes de milho tratadas associadas a polímeros durante o armazenamento. Ciência e Agrotecnologia, v.29, n.6, 1201-1208, 2005. http://www.scielo.br/pdf/cagro/v29n6/v29n6a14.pdf

PINTO, N.F.J. A. Tratamento fungicida de sementes de milho contra fungos do solo e o controle de Fusarium associado às sementes. Scientia Agricola, v.57, n.3, p.483-486, 2000. http://www.scielo.br/pdf/sa/ v57n3/2679.pdf
RIVAS, B.A.; McGEE, D.C.; BURRIS, J.S. Evaluación del potencial de polímeros como agentes envolventes de fungicidas en el tratamiento de semillas de maíz para el control de Pythium spp. Fitopatologia Venezuelana, v.11, n.4, p.471-488, 1998. http://sian.inia.gob.ve/ repositorio/revistas_ci/Agronomia\%20Tropical/at4804/arti/arias_b.htm

SCHUCH, L.O.B.; NEDEL, J.L.; ASSIS, F.N.; MAIA, M.S. Vigor de sementes e análise de crescimento de aveia preta. Scientia Agricola, v.57, n.2, 305-312, 2000. http://www.scielo.br/pdf/sa/v57n2/v57n2a18.pdf

TAYLOR, A.G.; HARMAN, G.E. Concepts and technologies of selected seed treatments. Annual Review of Phytopathology, v.28, p.321-339, 1990. http:// www.annualreviews.org/doi/pdf/10.1146/annurev.py.28.090190.001541

TILLMANM, M.A.A.; MIRANDA, D.M. Análise de sementes. In: PESKE. S.T.; LUCCA FILHO, O.A.; BARROS, A.C.S.A. (Ed.). Sementes: fundamentos científicos e tecnológicos, Pelotas: UFPel, 2006, p.159-255. 